\title{
Hypoglycemic effect of Phaleria macrocarpa (Scheff.) Boerl dry extract in healthy adults
}

\author{
Meiyanti*, Eveline Margo**, Pusparini***, Lie Tanu Merijanti ${ }^{\dagger}$, \\ and Alvina Lesmana $* * *$
}

\begin{abstract}
\section{BACKGROUND}

The prevalence of diabetes in Indonesia continues to increase and causes many complications. Fruits of Phaleria macrocarpa (Scheff.) Boerl. (PM) are used in the traditional health system of the Indonesians, as effective remedy in the management of diabetes mellitus. The aim of this study was to evaluate the effect and magnitude of doses of PM dry fruit extract (PME) on blood glucose levels in healthy adults.
\end{abstract}

\section{METHODS}

This research was of pre-posttest design involving 30 healthy volunteer subjects aged 20-55 years receiving glucose loads. At pre-test the subjects were given orally $75 \mathrm{~g}$ glucose, and at post-test they were given PME at doses of $125 \mathrm{mg}$ and $250 \mathrm{mg}$. Data collection included anthropometric examination and blood glucose level. The area under the curve (AUC) of blood glucose levels was measured at $0,15,30,60,120$, and 180 minutes. Data analysis was performed using paired t-test with $\mathrm{p}<0.05$.

\section{RESULTS}

The percentage of reduction in AUC between pre- and post-test after administration of PME $125 \mathrm{mg}$ was $12.1 \%$ and significant $(\mathrm{p}=0.000)$. But the percentage of reduction in AUC between pre- and post-test after administration of PME $250 \mathrm{mg}$ was $4.07 \%$ and not significant $(\mathrm{p}=0.06)$. The reduction in AUC between post-test PME $125 \mathrm{mg}$ vs PME $250 \mathrm{mg}$ showed significant results $(\mathrm{p}=0.011)$.

\section{CONCLUSION}

This study demonstrated that a dose of $125 \mathrm{mg}$ Phaleria macrocarpa (Scheff.) Boerl. dry extract has a hypoglycemic effect in healthy adults, and may therefore be suitable for use as traditional anti-diabetic drug.

Keywords: Phaleria macrocarpa, extract, blood glucose, healthy adult
*Department of Pharmacology and Medical Pharmacy, Faculty of Medicine, Trisakti University, Jakarta

**Department of Physiology, Faculty of Medicine,

Trisakti University, Jakarta

***Department of Clinical Pathology, Faculty of Medicine,

Trisakti University, Jakarta

'Department of Occupational Health, Faculty of Medicine,

Trisakti University, Jakarta

\section{Correspondence:}

dr. Meiyanti, SpFK

Department of Pharmacology and Medical Pharmacy, Faculty of Medicine, Trisakti University Jalan Kyai Tapa No 260 - Grogol, Jakarta - Indonesia

Phone: $+6221-5672731$ ext 2805

Email:meiyanti_suhardi@yahoo.com ORCID ID: orcid.org/0000-00021770-5504

Date of first submission, August 14, 2018

Date of final revised submission, November 14, 2018

Date of acceptance, November 14, 2018

This open access article is distributed under a Creative Commons AttributionNon Commercial-Share Alike 4.0 International License

Cite this article as: Meiyanti, Margo E, Pusparini, et al. Hypoglycemic effect of Phaleria macrocarpa (Scheff.) Boerl dry extract in healthy adults. Univ Med 2018;37:195-202. doi: 10.18051/

UnivMed.2018.v37.195-202 


\section{INTRODUCTION}

The use of traditional medications of plant origin (herbals or jamu) is steadily increasing in Indonesia, as indicated by the increasing number of herbal-producing industries. Some of the reasons for the increasing use of herbals are their ready availability, lower prices and traditional medicinal effects.

On the other hand, the use of traditional herbals in the community is as yet empirical, so that their quality, medicinal effects, and safety are in doubt. To raise the status of herbals to that of phytopharmaceutical or phytotherapeutic medications, it is imperative to test these herbals on humans through clinical trials.

One of the medicinal plants that is widely used in the community is Phaleria macrocarpa (Scheff.) Boerl. (PM), locally known as mahkota dewa. Phaleria macrocarpa belongs to the division of Spermatophyta, subdivision Angiospermae, class Dicotyledonae, order Celastrales, family Thymelaceae and genus Phaleria. This plant originates from Papua and is also known as Phaleria papuana Warb. var. wichannii (Val.) Back. ${ }^{(1)}$ Four parts of the plant are used in herbal medicine, namely the stem, leaf, seed coat and fruit. The stem is used for bone cancer, while the leaf is for impotence, blood disorders, allergy and diabetes mellitus. The fruit of PM contains alkaloids, saponins, flavonoids, and polyphenols that are frequently used as antioxidants. ${ }^{(2,3)}$ Phaleria macrocarpa extracts prepared from different parts of the plant have a number of medicinal properties, such as anticancer, antidiabetic, antihyperlipidemic, antiinflammatory, anti-bacterial, anti-fungal, and antioxidant. $^{(4)}$

In the community PM is frequently used as alternative medication for the treatment of diabetes mellitus, in addition to oral antidiabetics. ${ }^{(5)}$ Diabetes mellitus (DM) is at present a global health problem. Data from several global studies state that DM is a serious health problem, which is caused by the increasing numbers of patients with DM from year to year. In 2011 around 366 million adults suffered from DM, a fourfold increase from the 108 million in the 1980s, and it was estimated that in the year 2030 there would be a very large increase of up to 551 million in the number of patients with DM. ${ }^{(6)}$

Several in vitro studies and in vivo studies on animals indicate PM's effect as an antidiabetic. In the study by Ali et al. ${ }^{(3)}$ on rats it was concluded that a methanol extract of PM fruit pericarp has hypoglycemic effects. The study of Triastuti et al. ${ }^{(7)}$ concluded that PM has nephroprotective effects through PM's anti-hyperglycemic and antioxidant effects. The study by Ali et al. ${ }^{(8)}$ concluded that PM fruit pericarp methanol extract is able to decrease hyperglycemia in vitro as well as in vivo through inhibition of carbohydrate hydrolyzing enzymes. From several studies it is apparent that by using methanol as solvent, a higher content of active compounds may be obtained from PM, but since methanol is known to be toxic, it cannot be used as a commonly recognized safe solvent. ${ }^{(9)}$ In contrast to the foregoing studies, the study conducted by Hending ${ }^{(10)}$ states that the leaves of PM have antidiabetic effects. The study of Meiyanti ${ }^{(11)}$ concluded that PM pericarp powder at a dose of $500 \mathrm{mg}$ can decrease the blood glucose level of healthy persons after a glucose load. Although there are many studies on evaluation of the hypoglycemic effect of PM fruit pericarp extract (PME) in animals, there is scanty information on the hypoglycemic effect of PME in healthy adult humans. In addition, to date the extracts of PM have not yet been sufficiently standardized to yield detailed quantitative information of their phytoconstituents. ${ }^{(12)}$ The preparation of PM from the grinding and drying, up to the selection of extraction method and solvent to be used, will affect the efficacy and phytochemical contents of PM. ${ }^{(13,14)}$ Accordingly there is a need to conduct a study for evaluation of the hypoglycemic effect of PME in healthy human adults using a different solvent, with administration of the extract at several doses. 


\section{METHODS}

\section{Research design}

This study was of experimental pre-post test design and was conducted in the kelurahan (village) of Angke, kecamatan (district) of Tambora, Jembatan Dua, West Jakarta from February until April 2018.

\section{Study subjects}

This study used a sample size of 30 subjects, which was calculated using $\alpha=5 \%, Z \alpha=1.96$, $\beta=20 \%$, and $Z \beta=0.842$, with $S D=17.86$ and mean difference ("X) $=9.84 \mathrm{mg} / \mathrm{dL}$. ${ }^{(11)}$ The minimum number of subjects required was 26 , but in anticipation of a drop-out level of $15 \%$, the total number of subjects was increased to 30 .

The subjects were selected by consecutive non-random sampling. The inclusion criteria were as follows: i) males and females aged 18-55 years, ii) with body mass index of $\geq 18.5-25 \mathrm{~kg} / \mathrm{m}^{2}$, iii) not suffering from chronic diseases such as hypertension and diabetes mellitus, iv) not consuming certain herbal preparations (jamu) or vitamin supplements, from 1 week prior to the start of the study up to the completion of the study, v) not consuming caffein-containing beverages and fruit juice and not smoking within the last 24 hours, vi) agreeing to participate in the study and to sign a declaration of informed consent. The exclusion criteria were: i) being currently pregnant or breast-feeding, ii) consuming other medications, such as corticosteroids, that may affect the blood glucose level, from 1 week prior to the start of the study up to the completion of the study, iii) having participated in other studies in the 3 months prior to the present one.

\section{Plant material collection and preparation of extracts}

The preparation used in this study consisted of capsules containing a dry extract of PM pericarp (PME). The PM pericarp (without seed coat and seed) was obtained from plant nurseries in the region of Semarang, Central Java. The harvested pericarp was cut up and oven-dried at
$40 \mathrm{p} \mathrm{C}$ for 1 day. The dried pericarp was then ground into a powder, from which an extract was prepared with water and ethanol as solvents. ${ }^{(15)}$ The prepared extract was placed in gelatin capsules, with half their number containing 125 mg PME and the remaining capsules containing $250 \mathrm{mg}$ PME, but of identical appearance.

\section{Intervention}

The intervention given consisted of the administration of one of the capsules containing PM dry pericarpextract (PME) from Semarang, Central Java. At each visit the subjects received 400 calories (or 75 gram of glucose), in accordance with the glucose oral tolerance test procedure. ${ }^{(16)}$ At the first visit the subjects received a glucose load only, whereas at the following visit on day 4 , each subject received $125 \mathrm{mg}$ PME. After a wash-out period of 1 week, at the next visit on day 11 the subjects received $250 \mathrm{mg}$ PME. The doses used in this study were based on a previous study, which found that 500 mg of PM fruit powder has hypoglycemic effects and that one gram of PM fruit powder yields $250 \mathrm{mg}$ of extract, so that the present trial was conducted with the doses of $125 \mathrm{mg}$ and 250 mg PME. ${ }^{(11)}$

\section{Parameter for evaluation of hypoglycemic effect}

The parameter used to determine the subjects' responses to glucose loading was the area under the curve (AUC). ${ }^{(17)}$ The hypoglycemic effect of the PME was determined by using the AUC of the serum glucose level of healthy volunteers who did not receive the PME and acted as controls, to be compared to the AUC of the serum glucose level of subjects receiving the PME at doses of 125 $\mathrm{mg}$ and $250 \mathrm{mg}$. The AUCs were calculated with the trapezium formula ${ }^{(18)}$ for each respective intervention:

$$
\begin{aligned}
\mathrm{AUC}_{0-\mathrm{n}}= & \mathrm{t}_{1}-\mathrm{t}_{0} / 2 \cdot\left(\mathrm{C}_{0}+\mathrm{C}_{1}\right)+\mathrm{t}_{2}-\mathrm{t}_{1} / 2 .\left(\mathrm{C}_{2}+\mathrm{C}_{1}\right) \\
& +\ldots \ldots+\mathrm{t}_{\mathrm{n}}-\mathrm{t}_{\mathrm{n}-1} / 2\left(\mathrm{C}_{\mathrm{n}}+\mathrm{C}_{\mathrm{n}-1}\right)
\end{aligned}
$$




\section{Measurement of blood glucose level}

The blood glucose level was determined in accordance with the oral glucose tolerance test standard procedure. Each of the blood samples was drawn from the cubital vein and then tested prior to the oral glucose load and respectively at $15,30,60,120$ and 180 minutes ${ }^{(16)}$ after the oral glucose load and administration of the PMEcontaining capsules. The serum glucose level was measured in duplicate using the glucose oxidase-phenol and 4-aminophenazone (GODPAP) enzymatic colorimetric assay that had been validated with a Perkin-Elmer Lambda 3B spectrophotometer. The reagent used was Glucose GOD FS from DiaSys, Germany. Prior to the study, calibration curves were constructed and validation tests were performed on the measurement method, consisting of tests of accuracy, precision, and stability.

\section{Statistical analysis}

The AUC of the blood glucose level was calculated using the trapezoidal rule for a period of 3 hours ( $\mathrm{AUC}_{0-3}$ hours). The Kolmogorov test of normality of the data distribution showed that the data were normally distributed. The characteristics of the subjects were presented as mean $\pm \mathrm{SD}$. The absorbed amount of the ingested glucose with or without PME was statistically compared with the paired t- test. Differences at $\mathrm{p}<0.05$ were considered significant.

\section{Ethical clearance}

This study obtained ethical clearance from the Faculty of Medicine, Trisakti University, under no. 123/KER/FK /XII/2017.

\section{RESULTS}

The subjects participating in this study totaled 30 males and females with mean age of $34.2 \pm 10.5$ years, with $19(63.33 \%)$ female subjects. The subject characteristics may be seen in Table 1.

Tests of accuracy and precision of the daily (within run) glucose level showed that the
Table 1. Distribution of features characteristics of the subject $(\mathrm{n}=30)$

\begin{tabular}{lc}
\hline Characteristic & $\mathbf{n}$ \\
\hline Age (years) & $34.17 \pm 10.5$ \\
Sex & \\
Female & $19(63.3)$ \\
Male & $11(36.7)$ \\
Weight $(\mathrm{kg})$ & $54.62 \pm 8.17$ \\
Height $(\mathrm{m})$ & $1.57 \pm 0.09$ \\
Body mass index (BMI) $\mathrm{kg} / \mathrm{m}^{2}$ & $22.06 \pm 2.12$ \\
\hline
\end{tabular}

Data were presented as mean $\pm \mathrm{SD}$, except for sex $n(\%)$

coefficient of variation (CV) for the normal controls (Merck Qualitrol ${ }^{\circledR}$ HSN) was $0.95 \%$ with accuracy (recovery) of $98.21 \%$, whereas for the high controls (Merck Qualitrol ${ }^{\circledR}$ HSP) the CV was $1.5 \%$ and accuracy $97.12 \%$. The tests of accuracy and precision of the day-to-day glucose level showed that for HSN the CV was $2.16 \%$ with accuracy of $98.35 \%$ whereas for HSP the CV was $3.05 \%$ with accuracy of $95.23 \%$.

The mean blood glucose levels of the study subjects at $0,15,30,60,120$ and 180 minutes after glucose loading, without administration of PME (pre-test), as compared with post-test administration of PME at doses of 125 and 250 $\mathrm{mg}$, may be seen in Figure 1. Peak blood glucose level with or without administration of PME was reached within 30 minutes after glucose loading, whereas the lowest level was reached within 180 minutes ( 3 hours) after glucose loading.

Pre-test glucose level within the first 30 minutes (glucose peak) was $122.45 \pm 20.98 \mathrm{mg} /$ $\mathrm{dL}$, while for post-test PME doses of $125 \mathrm{mg}$ and $250 \mathrm{mg}$ the results were $107.09 \pm 20 / 98 \mathrm{mg} /$ $\mathrm{dL}$ and $117.6 \pm 21.80 \mathrm{mg} / \mathrm{dL}$, respectively. The decrease in glucose level at the glucose peak was $12.5 \%$ and $3.96 \%$ for post-test PME doses of $125 \mathrm{mg}$ and $250 \mathrm{mg}$, respectively, as compared with pre-test levels. The area under the curve for blood glucose level up to 3 hours $\left(\mathrm{AUC}_{0-3}\right.$ hours) was calculated using the trapezoidal rule. For the post-test PME dose of $125 \mathrm{mg}$ there was a decrease in blood glucose level, with mean decrease in $\mathrm{AUC}_{0-3}$ hours of $12.1 \%$, which was 


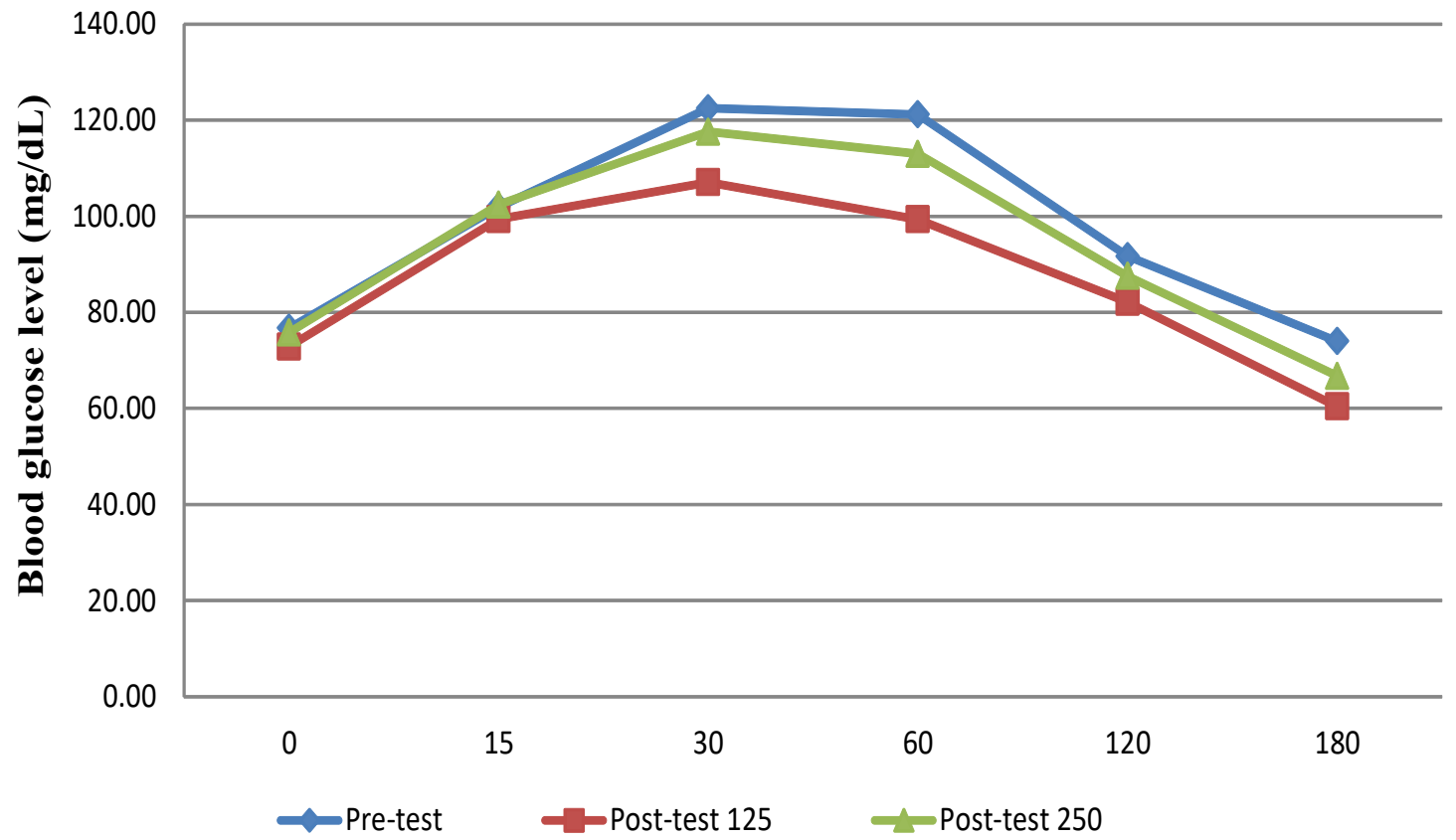

Time (min)

Figure 1. The effect of Phaleria macrocarpa extract on blood glucose level (mg/dL) of subjects

Data were expressed as mean $\pm \mathrm{SD}$

higher than the decrease for the post-test PME dose of $250 \mathrm{mg}$. The post-test PME dose of 125 $\mathrm{mg}$ resulted in a significant decrease in AUC $(\mathrm{p}=0.000)$, whereas the pre-test AUC and the post-test PME dose of $250 \mathrm{mg}$ did not differ significantly ( $\mathrm{p}=0.06)$ (Table 2$)$. A significant difference in AUC was also obtained for the post-test PME dose of $125 \mathrm{mg}$ as compared with the dose of $250 \mathrm{mg}(\mathrm{p}=0.011)$.

Prior to ingesting the PME, each of the subjects underwent physical examinations with respect to blood pressure, pulse rate, and clinical condition of the heart, lungs and abdomen. These examinations were also performed at each subsequent visit to obtain a continuous picture of the effect of PM on the vital functions and on complaints emerging during the administration of PME.

There were 2 subjects who complained of a bloated stomach after receiving PME at 250 $\mathrm{mg}$, whereas after administration of $125 \mathrm{mg}$ of PME there were no subjects who had complaints during the course of the study. A number of subjects who received PME showed a reduction in blood pressure. After administration of 125 mg PME there was a reduction in blood pressure of $5-7 \%$ in 4 out of the 30 subjects, whereas after administration of $250 \mathrm{mg}$ PME there were 10 out of the 30 subjects who had a blood pressure reduction of $10-12 \%$.

Table 2. Effect of Phaleria macrocarpa extract on blood glucose level and area under the curve

\begin{tabular}{lccccccc}
\hline \multicolumn{1}{c}{ Variable } & Pre-test & $\begin{array}{c}\text { Post-test } \\
\text { PME 125 } \mathbf{~ m g}\end{array}$ & $\begin{array}{c}\text { \% } \\
\text { diff }\end{array}$ & p & $\begin{array}{c}\text { Post-test } \\
\text { PME 250 } \mathbf{~ m g ~}\end{array}$ & $\begin{array}{c}\text { \% } \\
\text { diff }\end{array}$ & p \\
\hline Blood glucose* & $122.45 \pm$ & $107.09 \pm$ & 12.5 & $0.04 * *$ & $117.6 \pm$ & 3.96 & 0.384 \\
(mg/dL) & 20.98 & 20.98 & & & 21.80 & & \\
AUC & $18034.83 \pm$ & $15660.18 \pm$ & 12.1 & $0.000^{* *}$ & $17092.9 \pm$ & 4.07 & 0.06 \\
(mg.min/dL) & 2688.97 & 2707.28 & & & 2444.57 & & \\
\hline
\end{tabular}

*Blood glucose at 30 minutes; *\% difference between pre-test and post-test; **p $<0.05$ significant difference (paired t-test) 


\section{DISCUSSION}

Our study results show that within 30 minutes after administration of the PME dose of $125 \mathrm{mg}$ there was a higher mean reduction in blood glucose level as compared with administration of $250 \mathrm{mg}$ PME. Differing results were obtained in the study of Ali et al. ${ }^{(3)}$ on rats, showing that administration of PMEs in petroleum ether, methanol, or water did not have an effect in the acute dose hypoglycemic test, but that the methanol and aqueous extracts showed a nonsignificant decrease in blood glucose between 30 and 120 minutes in the intra-peritoneal glucose test.

The evaluated parameter was the area AUC because the effect to be evaluated was the response of the blood glucose level on administration of PME. In our study there was a better hypoglycemic effect at a PM dose of 125 $\mathrm{mg}$ as compared with a dose of $250 \mathrm{mg}$. This shows that the methods of pre-extraction and extraction, as well as the solvent used in the extraction process, will influence the concentration and phytochemical constituents of PM. In addition, the point to be considered is the region from which the PM fruits come. The active constituents contained depend very much on the plant parts used (leaf, stem, or fruit) and on the type of solvent used in the preparation of the extract. ${ }^{(12,19)}$ Region of origin, type of soil, growing medium, and fertilizers used will affect the mineral content of the fruit. ${ }^{(20)}$

The four parts of the PM plant that are frequently used in the community are the stem, leaf, pericarp, and fruit. Previous studies on the chemical composition of the pericarp and pericarpof PM found alkaloids, saponins, flavonoids, and polyphenols. ${ }^{(21-23)}$ The decrease in blood glucose is effected by the action of saponins and flavonoids. The effect of saponin on the cell membrane inhibits the absorption of the smaller nutrient molecules that should be absorbed, such as glucose, Abnormalities in cell structure are thought to cause disturbances in the glucose transporter system, leading to inhibition of glucose absorption. ${ }^{(15)}$ The study of Sabina et al. ${ }^{(24)}$ concluded that the decrease in blood glucose level after administration of PME is presumably due to inhibition of $\alpha$ - glucosidase, which is an intestinal enzyme that converts disaccharides into glucose. This enzyme acts to inhibit glucose absorption in the small intestine. The antidiabetic activity of PM through inhibition of $\alpha$-glucosidase was also concluded by Elya et al. ${ }^{(5)}$

The fruit of PM is thought to contain flavonoids that can increase insulin secretion, alter the metabolism of $\mathrm{Ca}^{2+(25)}$ and regenerate the pancreatic islets of Langerhans, particularly the $\beta$-cells. ${ }^{(26)}$ Similar findings were obtained in the study that was conducted by Arjadi and Mustafa (27) who concluded that PME can decrease the blood glucose level in diabetic rats, and regenerate the cells of the pancreatic islets of Langerhans of diabetic rats.

The decrease in blood glucose level as a result of PME administration is presumably effected through 2 main mechanisms, i.e. intrapancreatic by repairing the $\beta$-cells of the islets of Langerhans and by stimulating insulin release. The increased insulin secretion is due to sympathomimetic stimulation by the alkaloid, causing increases in insulin secretion. The flavonoids contained in PME have antioxidant effects that protect against damage to the cells of the pancreas from free radicals. The second mechanism is extra-pancreatic, through inhibition of intestinal glucose absorption by the alkaloids. ${ }^{(28)}$

The complaint found among the subjects was a sense of bloating in the stomach after administration of the PME dose of $250 \mathrm{mg}$, which may be caused by the rather high saponin content $(20.4 \%)^{(11)}$ in PM fruits that causes gastric irritation. In addition, there was also a decrease in blood pressure of the subjects after administration of both the PME doses of $125 \mathrm{mg}$ and $250 \mathrm{mg}$. This decrease in blood pressure is the result of the action of PM fruit as ACE inhibitor. $^{(29)}$

The main limitation of this study is its design as a pre-post test experimental study without controls, so that further studies should be 
conducted in accordance with the standards of a good clinical trial (randomized, using controls, and conducted on patients with diabetes). The clinical implication of this study is that dry PM fruit extract has antidiabetic effects, so that it can be used both as medication for the prevention of diabetes and as additional medication in patients with diabetes. The recommendation for further studies is to conduct a clinical trial in patients with diabetes comparing the extract to standard antidiabetics, so as to find more on the efficacy of PM as an antidiabetic. Biologically active plant extracts may be further exploited in the future by pharmaceutical and nutraceutical industries.

\section{CONCLUSIONS}

Phaleria macrocarpa extract has hypoglycemic effects on blood glucose level in healthy adult humans. The PME dose of $125 \mathrm{mg}$ has better hypoglycemic efficacy than the dose of $250 \mathrm{mg}$.

\section{CONFLICT OF INTEREST}

The investigators state that there is no conflict of interest in this study.

\section{ACKNOWLEDGMENTS}

The investigators thank the Faculty of Medicine Trisakti University and Trisakti University Research Institute (Lembaga Penelitian Universitas Trisakti) for the funding of the study. Thanks are also due to the Dhammasavana Foundation and all healthy volunteers who agreed to participate in this study.

\section{CONTRIBUTORS}

M contributed to study concept, design and drafting manuscript. EM and $\mathrm{P}$ contributed to acquisition of data and critical revision of manuscript for intellectual content. AL and LTM contributed to data analysis and critical revision of manuscript for intellectual content. All authors have read and approved the final manuscript.

\section{REFERENCES}

1. Govindappa M. A review on role of plant(s) extracts and its phytochemicals for the management of diabetes. J Diabetes Metab 2015; 6:565. doi: 10.4172/2155-6156.10000565.

2. Lee SY, Mediani A, Nur Ashikin AH, et al. Antioxidant and $\alpha$-glucosidase inhibitory activities of the leaf and stem of selected traditional medicinal plants. IFRJ 2014;21:165-72.

3. Ali RB, Atangwho IJ, Kuar N, et al. Hypoglycemic and antihyperglycemic study of Phaleria macrocarpa fruits pericarp. J Med Plant Res 2012; 6:1982-90. doi: 10.5897/JMPR11.1683.

4. Othman SNAM, Sarker SD, Nahar L, et al. The ethnomedicinal, phytochemical and pharmacological properties of Phaleria macrocarpa (Scheff). Boerl. Tang Humanitas Med 2014;4:1-11. DOI: http://dx.doi.org/10.5667/ tang2014.0018.

5. Elya B, Handayani R, Sauriasari R, et al. Antidiabetic activity and phytochemical screening of extracts from Indonesian plants by inhibition of alpha amylase, alpha glucosidase and dipeptidyl peptidase IV. Pak J Biol Sci 2015;18: 279-84. doi: 10.3923/pjbs.2015.279.284

6. International Diabetes Federation. Diabetes evidence demands real action from the UN summit on non-communicable diseases. Belgium: International Diabetes Federation;2011.

7. Triastuti A, Park HJ, Choi JW. Phaleria macrocarpa suppress nephropathy by increasing renal antioxidant enzyme activity in alloxan-induced diabetic rats. Nat Prod Sci 2009;15:167-72.

8. Ali R, Atangwho IJ, Kuar N, et al. In vitro and in vivo effects of standardized extract and fractions of Phaleria macrocarpa fruits pericarp on lead carbohydrate digesting enzymes. BMC Complement Alternative Med 2013;13:39. DOI: http://www.biomedcentral.com/1472-6882/13/39.

9. Kim W, Veriansyah B, Lee Y, et al. Extraction of mangiferin from mahkota dewa (Phaleria macrocarpa) using subcritical water. J Ind Eng Chem 2010;16:425-30. doi: 10.1016/j.jiec.2009. 08.008 .

10. Hending W, Ermin KW. Benzophenone glucoside isolated from ethyl acetate extract of the bark of mahkota dewa (Phaleria macrocarpa (Scheff) Boerl.) and its inhibitory activity on L1210 cel line. Indones J Chem 2009:142-5. DOI: http:// dx.doi.org/10.22146/ijc.473.

11. Meiyanti, Dewoto HR, Suyatna FD. Efek hipoglikemik daging buah Mahkota dewa (Phaleria Macrocarpa (Scheff) Boerl) terhadap 
kadar gula darah pada manusia sehat setelah pembebanan glukosa. Univ Med 2006;25:114-20.

12. Altaf R, Bin Asmawi MZ, Sadikin A, et al. Phytochemistry and medicinal properties of Phaleria acrocarpa (Scheff.) Boerl. extracts. Pharmacogn Rev 2013;7:73-80. doi: 10.4103/0973. 7847.112853.

13. Alara OR, Olalere OA. A critical overview on extraction of bioactive compounds from Phaleria macrocarpa (Thymelaceae). Nat Prod Chem Res 2016;4:5. DOI: http://dx.doi/10.4172/2329. 6836.10000232

14. Azwanida NN.A review on the extraction methods use in medicinal plants: principle, strength, and limitation. Med Aromat Plants 2015;4:3. DOI : http://dx.doi.org/10.4172/2167-0412.1000196.

15. Rahmi E. Wahyuni WT, Darusman LK, et al. Combination of ethanolic extract of $\alpha$-glucosidase inhibitory activity of (Phaleria macrocarpa (Scheff.) Boerl.) fruits and Annona muricata Linn. leaves. Trad Med J 2016;21:63-8. DOI: https:// doi.org/10/22146/tradmedj.12819.

16. Purnamasari D. Diagnosis dan klasifikasi diabetes mellitus. In: Setiati S, Alwi I, Sudoyo AW, editors. Buku ajar ilmu penyakit dalam Jilid II Edisi VI. Jakarta: Interna Publishing; 2014.p.2325-9.

17. Scheff JD, Almon RR, DuBois DC, et al. Assessment of pharmacologic area under the curve when baselines are variable. Pharm Res 2011;28: 1081-9. doi: 10.1007/s11095-010-0363-8.

18. Chotimah C, Sutrisna EM, Wahyuni AS. Water extract of jaka tuwa (Scoparia dulcis L) herb activity on lowering blood glucose on male rabbit that loaded with glucose. Pharmacon 2008;9:4651 .

19. Muhtadi A, Hendriani R, Mustarichie R. Pharmacological screening of various Indonesian herbal potentially used as antidiabetic. IRJPAS 2013;3:90-5. doi: 10.1038/ncomms9482.

20. Anggraeni DN. Pengaruh pemberian variasi dosis pupuk kandang terhadap pertumbuhan tanaman mahkota dewa (Phaleria macrocarpa (Scheff.) Boerl.). Biogenesis 2014;2:16-20.doi:https:// doi.org/10.24525/bio.v.2i1.463.
21. Ali RB, Atangwho IJ, Kuar N, et al. Bioassayguided antidiabetic study of Phaleria macrocarpa fruits extract. Molecules 2012;17: 4986-5002. doi: 10.3390/molecules17054986.

22. Azmir J, Zaidul ISM, Sharif KM, et al. Supercritical carbon dioxide extraction of highly unsaturated oil from Phaleria macrocarpa seed. FRIN 2014; 65:394-400. doi: 10.1016/j.foodres2014.06.049.

23. Andrean D, Prasetyo S, Kristijarti AP, et al. The extraction and activity test of bioactive compounds in Phaleria macrocarpa as antioxidants. Procedia Chem 2014;9:94-101. doi: 10.1016/j.proche.2014.05.012.

24. Sabina E, Zaidul ISM, Ghafoor K, et al. Screening of various part of macrocarpa plant for $\alpha$ glucosidase inhibitory activity. J Food Biochem 2016; 40:201-10. DOI: https://doi.org/10.1111/ jfbc.12212.

25. Ramachandran B, Rajasekaran S. Blood glucose lowering effect of Tectona grandis flowers in type 2 diabetic rats: a study on identification of active constituents and mechanisms for antidiabetic action. J Diab 2014;6:427-37. doi: 10.1111/17530407.1212.

26. Cicero L, Yenshou L, Arlene PB, et al. Herbal therapies for type 2 diabetes mellitus: chemistry, biology, and potential application of selected plants and compounds. Evidence-based Comp Alt Med 2013;33-6. DOI: http://dx.doi.org/ 10.1155/2013/378657.

27. Arjadi F, Mustofa. Ekstrak daging buah mahkota dewa meregenerasi sel Pulau Langerhans pada tikus putih diabetes. Biogenesis 2017;5:27-33. DOI: http://dx.doi.org/10.24252/bio.v4i2.3430.

28. Aziz MTA, El-Asmar MF, Rezq AM. The effect on a novel curcumin derivative on pancreatic islet regeneration in experimental type 1 diabetes in rats (long term study). Diabet Metab Synd 2013;5: 75. doi: 10.1186/1758-5996-5-75.

29. Hendra R, Achmad S, Sukari S, Shukor YM. Flavonoid analyses and antimicrobial activity in various parts of Phaleria macrocarpa (Scheff.) Boerl fruit. Int J Mol Sci 2011:3422-3.doi:10.3390/ ijms12063422. 